\title{
Vrijmoedig spreken
}

Citation for published version (APA):

Huijer, M. (2003). Vrijmoedig spreken: publieke gesprekken over gender en biotechnologie. Maastricht University. https://doi.org/10.26481/spe.20030214mh

Document status and date:

Published: 14/02/2003

DOI:

10.26481/spe.20030214mh

Document Version:

Publisher's PDF, also known as Version of record

\section{Please check the document version of this publication:}

- A submitted manuscript is the version of the article upon submission and before peer-review. There can be important differences between the submitted version and the official published version of record.

People interested in the research are advised to contact the author for the final version of the publication, or visit the DOI to the publisher's website.

- The final author version and the galley proof are versions of the publication after peer review.

- The final published version features the final layout of the paper including the volume, issue and page numbers.

Link to publication

\footnotetext{
General rights rights.

- You may freely distribute the URL identifying the publication in the public portal. please follow below link for the End User Agreement:

www.umlib.nl/taverne-license

Take down policy

If you believe that this document breaches copyright please contact us at:

repository@maastrichtuniversity.nl

providing details and we will investigate your claim.
}

Copyright and moral rights for the publications made accessible in the public portal are retained by the authors and/or other copyright owners and it is a condition of accessing publications that users recognise and abide by the legal requirements associated with these

- Users may download and print one copy of any publication from the public portal for the purpose of private study or research.

- You may not further distribute the material or use it for any profit-making activity or commercial gain

If the publication is distributed under the terms of Article $25 \mathrm{fa}$ of the Dutch Copyright Act, indicated by the "Taverne" license above, 


\section{Vrijmoedig spreken}

Publieke gesprekken over gender en biotechnologie 


\section{Collofon}

Eavisontwerp en realisatie. Unigraphic, Universtet Maastricht Hustratie omshag: Buro jan-zE

$158 N 90-5631-152-5$

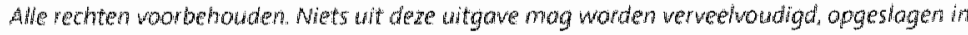
een geautomotiserd gegevenswestand of openbar genoakt zonder vorafgande schriftelifke toestemming van de auteur of uitgever. 


\section{Vrijmoedig spreken \\ Publieke gesprekken over gender \\ en biotechnologie}

\section{Rede}

Uitgesproken bij de aanvaarding van het ambt van Bijzonder Opzij hoogleraar Macht en Strategie:

Gender en biomedisch/gezondheidswetenschappelijk onderzoek aan de Universiteit Maastricht op 14 februarï 2003

door

\section{Marli Huijer}

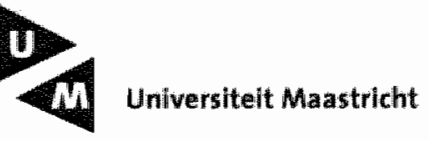


Voor Nico en Daan 


\section{Vrijmoedig spreken}

\section{Publieke gesprekken over gender en biotechnologie}

In 'De twee koningen en de twee labyrinten', een kort verhaal van Jorge Luis Borges, laat een koning van de eilanden van Babylonie een labyrint bouwen. Het is zo ingewikkeld en wijdwertakt dat zij die er binnengaan wel moeten verdwalen. Wanneer een Arabische koning hem bezoekt, nodigt de koning van Babylonie hem wit het labyrint te betreden. Na urenlang ronddolen vindt de Arabische koning de deur. Hij is beledigd en besluit de koning van Babylonie in zijn eigen labyrint uit te nodigen. Daartoe verwoest hij de rijken van $B$ abylonië, maakt de kastelen met de grond gelijk en neemt de koning gevangen. Het labyrint dat wordt vervaardigd is een lege woestijn, zonder muren, deuren, trappen - en - zo kunnen we zelf constateren - zonder de draad van Ariadne en zonder musjes die veren leveren om weg te vliegen. De koning van Babylonië wordt in het labyrint losgelaten. $U$ zult het begrijpen: hij stenft van honger en dorst.

Als we het labyrint als een metafoor woor democratie opvatten, ziet het eerste labyrint eruit als een doolhof van meningen waar je in verdwaald raakt als je niet consequent en gestaag alle meningen bevoelt, besnuffelt en beluistert. Wie het contact met de door anderen neergezette afbakeningen verliest, komt er niet uit. Het tweede labyrint is een leeggeroofde vlakte - alle meningen zijn vervakt, weggevaagd. Opvattingen zijn tot zandkorrels geworden die in uiterlijk nauwelijks van elkaar verschillen. In dit landschap kun je niet verdwalen, maar tegelijkertijd weet je niet waar je staat. In het eerste labyrint is vrijmoedig spreken niet zo moeilijk. Er zal altijd een ruimte te vinden zijn waar zelfs de meest verlegen persoon zijn mond open durft te doen. In het tweede labyrint is er maar én gedachte die telt: overleven. Vrijmoedig spreken heeft in deze ruimte geen $z \mathrm{in}$.

Een filosoof die zich decennia geleden al drulk maakte over het verdwijnen van het vrijmoedig spreken en handelen in publieke sferen en het op de voorgrond treden van de drang tot overleven was de DuitsAmerikaanse filosofe Hannah Arendt. Verwijzend naar de arbeid - lobor - die een vrouw werricht wanneer ze een kind baart, en daarmee de soort in stand houdt, stelde Arendt dat de moderniteit de samenleving heeft veranderd in een laboring society - een samenleving die gericht is op reproductie in de ruimste zin van het woord. Menszijn in een laboring society betekent dat we onze tijd wullen met het in stand houden van het. 
leven: gezond eten en drinken, elke week de koelkast schoommaken, de omhulsels van sigarettenpakjes lezen, naar de kapper gaan, regelmatig seks hebben, sporten, acht uur slapen, op tijd kinderen nemen, geduldig met hen in de rij stalan voor de vaccinaties, meewerken aan bevolkingsonderzoeken, elk jaar naar de tandarts en wooral niet te lang in de zon zitten.

Hoe belangrijk al deze activiteiten ook zijn, en hoe hoog gezondheid ook scoort op de verlanglijstjes van de gemiddelde Nederlander, menseligk leven is meer dan het in stand houden van biologische levensprocessen. Gezondheid heeft weinig tot geen warde als deze nergens toe dient. Hannah Arendt wijst erop dat er naast het arbeiden twee andere bezigheden zijn die het menszijn vormgeven: het werken, dat is het produceren van duurzame producten zoals gebouwen, bruggen en gebruiksvoorwerpen; en het hondelen, dat wil zeggen een initiatief nemen, iets nieuws beginnen, waarbij ledereen ook altijd eigen inzichten inbrengt en op die manier tracht een gemeenschappelijke wereld vol verschillen te creeren (Arendt 1998, 177 e.v.). Dat we de wereld volstouwen met menselijke werken behoeft geen betoog. Het is de derde activiteit, het handelen, die aandacht behoeft. Handelen is een politieke activiteit. Het vergt dat men tussen mensen is, te midden van de miljarden mensen die de aarde bevolken. De voorwaarde voor alle politieke leven, zo stelt Arendt, is de menselijke pluraliteit - de erkenning dat we daarin overeenkomen dat we allen verschillend zijn. Arendt maakt zich zorgen over het verdwijnen van het spreken en handelen, over het tekort aan politieke betrokkenheid bij elkaar. In een samenleving waarin het in standhouden van het biologische leven de menselijke conditie bepaalt, vervalt het inter-esse, datgene wat er tussen mensen is. Haar bezorgdheid klinkt door in de analyses van hedendaagse auteurs als. Nikolas Rose en Dorothy Nelkin die in navolging van de Franse filosoof Michel Foucault constateren dat het biologische bestaan van mensen een van de hoogste politieke doelen is geworden. Zijn we het soort mensen geworden die als het over ons heden en onze toekomst gaat, alleen stilstaan bij de kwaliteit van het biologische leven van onszelf en de onzen? vragen zij zich af.

Dergelijke vragen wil ik vandaag opnieuw stellen, maar dan toegespitst op publieke gesprekken over gender en biotechnologie. In hoeverre stellen wij in ons spreken, handelen en denken over biomedische wetenschappen en technologieèn de biologische processen van het menselijk lichaam voorop? in hoeverre worden andere menselijke condities en perspectieven terzijde geschoven of buitengesloten? Welke 
stem hebben vrouwen in de moderne technologisch-wetenschappelijke cultuur? Welke kansen hebben zij om hun kennis, ervaringen, verhalen, visies en alternatieve scenario's in te brengen in de onderhandelingen die op verschillende niveaus worden gevoerd over wetenschappelijke en technologische prioriteiten en de financiering van onderzoek? Welke democratische ruimtes bestaan of kunnen worden gecreëerd zodat vrouwen gelijkelijk acte de présence geven in het politieke biomedisch wetenschappelijke handelen?

in het volgende zall ik me eerst richten op technologieen die het biologische leven beheren - bio-technologieën.

\section{Bio-technologieën}

Wetenschappers zijn de enige die wandaag de dag nog in staat zijn de wereld te veranderen door te handelen, stelt Arendt aan het einde van The Human Condition - een boek dat in 1958 verscheen. Hun verrichtingen hebben grotere nieuwswaarde, zijn van groter pollitiek belang dan de administratieve en diplomatieke verrichtingen van de meeste politieke leiders. Zij weten nog te handelen - althans in de betekenis van het in gang zetten wan processen; en vooral weten zij eendrachtig te handelen (Arendt 1998, 324). Arendt spreekt met name over de toenmalige matuurwetenschappen. Haar analyse is inmididels evenzeer van toepassing op de biomedische wetenschappen.

In de driedeling die Arendt makt tussen arbeiden, werken en handelen is de moleculair bioloog halwerwege de vorige eeuw nog vooral een werkend mens, een homo faber die een voorspelbare en materiële wereld schept. Zo is de dubbele helix die Francis Crick en James Watson in 1953 in een klein laboratorium in het Britse Cambridge produceerden. eerder een product van werken dan een vorm van handelen. Ze creëerden met hun handen een materieel model - een wenteltrap met millarden treden - warvan we slechts de onderdelen hoeven te analyseren on de wereld en onszelf te begrijpen.

De ontwikkeling van DNA-recombinant technologieên begin jaren zeventig bracht verandering in het werkmanschap van de moleculair bioloog. Het werd mogelijk om stukken DNA te isoleren en deze in te brengen in andere chromosomen en andere organismen. Blowetenschappers en biotechnologen kregen van het ene op het andere moment instrumenten in handen wararmee ze nieuwe organismen konden creëren. Hun wetenschap en technologie werd een vorm van handelen, een wereldveranderende activiteit. De uitkomsten van de DNArecombinant techniek werden zo onvoorspelbaar geacht dat weten- 
schappers zelf een moratorium op deze techniek uitriepen. Na tal van openbare debatten werd dit moratorium na 2 jaar opgeheven (Fredrickson 19911). Genetische modificatie van bacterien, virussen, planten en dieren is sindsdien een gangbare wetenschapspraktijk geworden. Maar hoewel weterischappers voortdurend het publiek ervan trachten te overtuigen dat genetische modificatie geen risico's in zich draggt; blijven veel burgers een gevoel van onbehagen en onvoorspelbaarheid houden.

De afgelopen decennia zijn de mogelijkheden tot het in gang zetten van nieuwe processen, en daarmee het veranderen van de wereld explosief toegenomen. In 1978 werd het mogelijk een embryo buiten de baarmoeder te creêren. Rond 1985 werd een techniek ontwikkeid warmee stukken DNA eindeloos konden worden vermenigvuldigd - de Polymerase kettingreactie of PCR. In 1987 werd voor het eerst het gen van een erfelijke zlekte gekloond (chronische granulomatosis - een chronische ontstekingsziekte), gevolgd door de genen voor de spierziekte van Duchenne en erfelijke blindheid, taaislijmvliesziekte (1989), ziekte van Huntington (1993), erfelijke darmkanker (1993) en erfelijke borstkanker (1994). De introductie van genetische testen impliceerde een ingreep in de "natuurlijke selectie"; het werd feitelijk mogelijk om embryo's met genetische afwijkingen te aborteren. In 1990 startten de eerste experimenten met gentherapie bij mensen met aids, kanker en ander ernstige ziekten. Begin jaren negentig werd preimplantiediagnostiek (PID) geintroduceerd, waarbij genetische afwijkingen bij IVF baby's worden vastgesteld om zeker te zijn dat er een vrucht zonder afwijkingen in de baarmoeder wordt geplaatst. In 1997 werd het eerste gekloonde dier geboren. Eind jaren negentig lukte het om embryonale stamcellen te kweken en om te vormem tot zenuw., lever- en andere lichaamscellen. Het repareren van genetische afwijkingen in de baarmoeder of na de geboorte staat nog in de kinderschoenen maar zou op den duur toegevoegd kunnen worden aan het arsenal van biomedische handelingen. Ook de impuls op het gebied van de nanobiotechnologie - de keine deeltjes technologie waarbij het mogelijk is op atomair en moleculair niveau organisch en anorganisch material te weranderen - belooft een groot auntal nieuwe wormen van levende en niet-levende materie en mengvormen daartussen voort te brengen.

De reikwijdte en orwang van het biowetenschappelijk handelen is exponentiel toegenomen door de opzet rond 1990 van het internationale Human Genome Project. Het project is exemplarisch voor Arendt's constatering dat wetenschappers zeer goed in staat zijn tot eendrachtig 
handelen. Een relatief kleine club Amerikanse wetenschappers, die sinds decennia een hechte gemeenschap van onderzoekers vormde, ondersteund door overheidsinstituten, politici en bedrijfsleven, slaagde erin een grootschalig intemationaal samenwerkingsproject op te zetten met als doel vóór 2005 het hele genoom van mensen en andere "modelorganismen" te ontcijferen. In dit project stonden voor het eerst in de geschiedenis van de twintigste eeuw niet de genen (stukken DNA) mar het hele DNA of genoom (de 23 paar chromosomen opgebouwd uit 3 miljard basenparen) centraal. Het accent verschoof van overerving tussen generaties naar de erfelijke eigenschappen aanwezig in het individuele organisme. Inmiddels heeft de gedachte dat eén gen codeent woor én eiwit en daarmee voor één eigenschap plaatsgemaakt voor een model waran tal van complexe relaties bestaan binnen het DNA en tussen DNA en omgeving (Keller 200o). Een breed scala aan te onderzoeken relaties tussen DNA en functionerende organismen - en dammee een toenemende aantal mogelijkheden om veranderingen in het DNA aan te brengen - opent zich voor de ogen van hedendaagse moleculair biologen. Het aantal wetenschappers dat zich wereldwijd met DNA bezighoudt groeit met de dag.

De vlucht die de biomedische wetenschappen hebben genomen, kan niet alleen worden toegeschreven aan het handelen van wetenschappers. Arendt's analyse van de bevoorrechte positie van wetenschappers ten aanzien van het handelen, doet geen recht aan de politieke en economische context waarin de exponentiële groei wan de biomedische wetenschappen en technologieën zich voltrok. En belangrijke politieke mogelijkheidsvoorwaarde voor de enorme groei van de biomedische wetenschappen is de val van de muur. Het einde van de Koude Oorlog opende niet alleen mogelijkheden tot samerwerking met het Oostblok. maar luidde ook de triomf in van het vrije markt kapitalisme en de liberale democratie. Wetenschap raakte gelieerd aan economische doeleinden en minder dan voorheen aan militaire doeleinden. Wetenschap en technologie werden belangrijke partners in het zeker stellen van de economische concurrentiepositie van landen. Geschat wordt dat op dit moment meer dan $25 \%$ van de economische groei in Europa voorthomt uit onderzoek en technologie (NWO 2000, 7). Met de juiste investeringen - zoals recentelijk in genomics en nanotechnologie - zou dat in Nederland tot $50 \%$ kunnen oplopen. Dergelijke investeringen worden vanuit de overheid gepresenteerd als een noodzakelijke stap om te voorkomen dat Nederland een achterstand oploopt ten opzichte wan het buitenland - dat will zeggen Duitsland, Frankrijk, Engeland, Amerika en 
Canada TTijdelijke Adviescommissie Kennisinfrastructuur Genomics 2001, 19). De mogellikheden om wetenschappelijk onderzoek winstgevend te laten zijn, zign het afgelopen decennium flink uitgebreid. Overheden in Europa en Amerika voeren een actief octrooierings- en technologietransferbeleid orn universiteiten en kernnisinstellingen te stimuleren hun onderzoeksresultaten te vertalen in commerciele producten en dienster.

De toegenomen commercialisering van de biomedische wetenschappen maakt dat wetenschappers niet als enige besluiten over prioriteiten in het onderzoek - overheden, bedrifsleven en investeringsmaatschappijen hebben eveneens hun inbreng.

ook de maatschappelijke context waarin de biomedische wetenschappen tot bloei zijn gekomen, is niet te vergelijken met die waarin Hannah Arendt over wetenschappen schreef. De democratisering van de jaren zestig en zeventig, de tweede feministische golf, de antimedikaliseringsbeweging - gedragen door auteurs als Ivan Illich en Irving Zola hebben diepe sporen achtergelaten in het sociale, politieke en individuele leven. Burgers zijn aanzienlijk mondiger, beter opgeleid en kritischer ten opzichte van autoriteiten dan eind jaren vijftig. De democratisering van wetensichap, technologie en informatie hebben hier hun steentje toe bilgedragen, en zijn tegelijkertijd gevolg van de toegenomen mondigheid. Ook de opkomst van patiëntenorganisaties past in deze trend. Biomedische wetenschappen zijn bovendien geen gewone wetenschappen. Ze raken aan zaken die veel mensen bezighouden. Klonen, het gebruik van embryonale stamcellen en het genetisch modificeren wan voedsel zijn onderwerpen die de gemoederen van burgers flink in beroering brengen. Een toenemend aantal individuen, groepen, instituten en bedrijven is betrokken bij de ontwikkeling en implementatie van biomedische wetenschappen en praktijken. Sociale bewegingen, wrouwengrosperingen, journalisten, religieuzen, beleidsmakers, onderzoekscouncils, biotechnologiebedrijven en financieringsmaatschappijen spreken. handelen en onderhandelen in tal wan publieke en private sferen - variêrend van laboratoria, mediastudio's, vergaderzallen tot bij de kapper en in de kroeg. De context waarin kennis wordt geproduceerd, spreekt terug zoals Nowotny, Scott en Gibbons opmerken (2001). Zij betitelen de tegenwoordige samenleving als een Mode-2 society, een samenleving waarin het aantal mensen dat betrokken is bij onderzoek is toegenomen, waarin de definitie van wat wetenschappelijk onderzoek is. is opgerekt, en waarin op meerdere locaties vele vormen van kennis worden geproduceerd. De overgang van een Mode-1 society, die geregeerd 
wordt door relatief eenduidige kennis en wetenschappelijke rationaliteit, naar een Mode-2 society is het gevolg van globaliseringprocessen. het vervagen van de grenzen tussen private en publieke sferen, de afnemende macht vam nationale overheden en het ontstian van tal van anderhandelingszones tussen overheid en markt, markt en wetenschap en andere sectoren. De beschrijving die Nowotny. Scott en Gibbons geven van de Mode-2 society, doet denken aan het labyrint van de koning van Babylonië. De Mode-z society wordt gekenmerikt door een groeiende complexiteit, een toegenomen onzekerheid, een open systeem waarin diverse soorten kennis worden geproduceerd en geen eenwoudige oorzaakgevolg patronen te ontdekken zijn. We zich in het labyrint van de Mode-2 society begeeft merkt dat elk verband tijdelijk is. Niemand kan voorspellen waar de uitgang wan het labyrint is, ondat ruimtes wervormd raken en de muren verplaatst worden. Het is zelfs de vraag of er wel een centrum of een uitgang is.

Gesteld dat we inderdaad in een Mode-2 society leven, betekent dat dan dat Arendt's politieke ideaal wan handelen is bereikt? Handelen staat bij Arendt voor een initiatief nemen, iets mieuws beginnen, iets in beweging zetten - en dat gebeurt meestal door te spreken of iets te doen. Handelen houdt in dat we onszelf invoegen in de menselijke wereld, een eigen respons geven op de wereld waar we met onze geboorte in terecht zijn gekomen. Die eigen respons is het publieke antwoord van de nieuwkomer op de vraag "Wie ben jij?". De Mode-2 society lijkt de ideale architectuur voor deze vorm van menselijk politiek handelen. In de vele arena's van de Mode-2 society is er ruimte voor'gesprekken over wat mensen willen, wat hun behoeften zijn en hoe zelfs antwoor. den en claims die elkaar tegenspreken, beter ingelijfd kunnen worden in de interactieve dynamische uitwisseling tussen de kennis die geproduceerd wordt en de sociale context waarin dit gebeurt" (Nowotny. Scott en Gibbons 2001, 258). Mensen treden binnen in de overschrijdende arena's, uiten hun meningen, vertellen hun evaringen, organiseren zich wanneer ze over iets verontrust zijn, schrijven brieven, sturen stukken naar de krant, laten zich interviewen voor radio of tv maken geld over naar idealistische organisaties, zoeken contact met politieke partijen, en leggen hun belangen op tafel bij het bedrifsleven. Is daarmee de idee dat we een laboring society zijn van tafel? Kunnen we ervan uitgaan dat burgers in de hedendaagse Mode-2 society niet geregeerd worden door het verlangen on de kwaliteit van het biologische leven van zichzelf en hun naasten te maximaliseren?

Zoals eerder opgemerkt, wordt deze veronderstelling weersproken 
door Nikolas Rose en andere sociologen en filosofen. In mavolging van Michel foucault schetst Rose de hedendaagse burger als lemand die miet kan ontsnappen aan de wil tot gezondheid. De architectonische metafoor die foucault (1975) gebruikt om de disciplinering tot gezond burger te begrijpen, is het panopticum. Het is een gebouw waarin iedereen zonder dat zij of hij het ziet geobserveerd, in kaart gebracht en gedisciplineerd wordt. De metafoor van het panopticum staat voor een samenleving waarim alles van iedereen zichtbaar is en mensen op basis wan de informatie die over hen bekend is gedisciplineerd kunnen worden. De moderne genetica wordt binnen dit model geinterpreteerd als een worm van genetische surveillance. Deze bestaat hierin dat er middels het Human Genome Project een "consensusgenoom" wordt gecreeerd, dat als norm functioneert waarlangs het individuele DNA wordt afgezet. Tegelijkertijd worden er - in het kader van misdaadbestrijding, immigratie, opsporing van erfelike ziektes en om de identiteit vari slachtoffers zoals van de WTC-ramp vast te stellen - grote aantallen individuele DNA-mansters opgeslagen in wereldwijde databanken, en gekoppeld aan andere persoonsgegevens (Nelkin en Andrews 1999). Het genetische panopticum wordt geregeerd vanuit het centrum:

Alleen in het centrum van de dingen, aan de terminais die verbonden zijn met de centrale DNA-databases, kan men de vergelijkingen tussen individuele genoomsequenties maken die toelaten dat we anze macromolecu. laire gemeenschappelijkheid en differentie "vinden" (Flower en Heath 1993, 30-32).

De politiek die in de moderne transparante samenleving regeert is de "biopolitiek" - een politieke wil tot gezondheid, tot een veilig en risicoloos bestaan gericht op het bereiken van de hoogste kwaliteit van het biologische leven. Deze politiek wordt niet van bovenaf opgelegd, door overheid, artsen, wetenschappers, gezondheidsinstituties of dominees; burgers leggen deze zichzelf op. De biopolitiek is ingelijf: elke burger is actief partner in de zucht natar een gezond en risicoloos bestaan, en neemt vrijwillig zelf de verantwoordelijkheid op zich voor het eigen welbevinden. En hoewel ook Rose de samenleving als een complex kraclitenspel neerzet, leidt dit niet zoals bij Nowotny, Scott en Gibbons tot een pluraal menselijk handelen, maar tot een eensluidende kreet om veiligheid en gezondheid. Die eensluidendheid wordt ondersteund door economische krachten. Met het verlangen naar gezondheid valt immers geld te verdienen: 
Van deze nieuwe "wil tot gezondheid" wordt in toenemende mate geprofiteerd door ondernemingen, varierend van farmaceutische bedigiven tot voedselleveranciers. En een heel scala aan actiegroepen, organisaties die campagnes woeren en zelfhulpgroepen bezetten de ruimte van verlangens, angsten, teleurstellingen en kwalem die zich utstrekt tussen de wil tot gezondheid en de ervaring dat gezondheid ontbreekt. Binnen dit complexe netwerk van krachten en beelden wordem de gezondheidsgevela teerde ambities en gedragingen wan individuen "op afstand" geregeerd door worm te geven aan de manieren waarop zij hum eigen wrijheid begrijpen en waststellen (Rose 2001,6 ).

Tot op zekere hoogte klopt de analyse van Rose. Het valt niet te ontkennen dat gezondheid een van de hoogste waarden in de westerse cultur is, en dat de verantwoordelijkheid voor het eigen welbevinden meer en meer op de schouders van de individuele burger is komen te liggen. In zekere zin zijn we in het labyrint van de Arabische koning beland waar consensus heerst en alle verschillen zijn weggevallen. Het enige geluid dat tell is dat van de mens-koning die wil overleverin. Tege ijkertijd is Rose' analyse ongeloofwaardig. Hij veronderstelt dat geen mens - of hooguit de filosoof - in staat is voorbij de consensus over het belang van gezondheid te denken, en dat ledereen zich laat regeren door verlangens die het biologische leven betreffen. Dat is in tegenspraak met de scepsis die publiekelijk wordt geuit over de wikkels om sigarettenpakjes, de niet altijd even grote bereidheid om deel te nemen aan bevolkingsonderzoeken of genetische testen, de hoge alcoholconsumptie in ons land, en de hoge waardering van mobiliteit, lekker eten en andere bezigheden die niet altijd even gezond zijn. Rose'eenduidige interpretatie van de moderne biotechnologische cultuur is ook niet in overeenstemming met de resultaten uit empirische studies. De analyse van Nowotny, Scott en Cibbons lat overtuigend zien dat er andere en meerdere filosofische en politieke perspectieven naast elkaar kunnen bestaan - zoals dat ook bij Arendt het geval is. Een laatste argument naar aanleiding van Rose' analyse is dat de politieke zorg om het biologische lichaam niet slechts voortkomt uit een nieuwe wil tot gezondheid, maar tevens een gevolg is van de veranderde taakverdeling tussen mannen en vrouwen. Traditioneel was de zorg woor het biologische leven (arbeid in Arendt's termen) een taak woor vrouwen. Zij baarden, deden het huishouden en zorgden voor de kinderen. Mannen werkten en handelden. Met de toetreding van vrouwen tot het domein van werken en handelen, is de zorg voor het biologische leven ook een zaak voor mannen geworden. En een 
meer publieke zaak. omdat mannen de zorg niet voor $100 \%$ overnemen. De pubilieke aandacht voor biologische processen hoeft niet te leiden tot een monomane biopolitiek. Zolang andere perspectieven, vertogen, verhalen en menselijke condities eveneens en met een zelfde overtuigingskracht in private en publieke ruimtes aan de orde komen, is er geen reden te gelowen dat wij slechts geregeerd worden door de wil tot gezondheid.

\section{Vrouwen als product, gebruiker en burger}

In het vervolg zal ik mij buigen over de vraag hoe in de Mode-2 society publieke gesprekken kunnen worden gevoerd over biotechnologie, en hoe een diversiteit aan perspectieven kan worden ingebracht en behouden. Ik zal dat doen vanuit het perspectief wan vrouwen - een term die ik met aarzeling gebruik omdat deze geen uitdrukking geeft aan de vele verschillen tussen vrouwen en het risico in zich draagt dat mensen gereduceerd worden tot hun biologische sekse. Toch drukt de term wrouwen beter dan het begrip gender uit dat mensen van het vrouwelijke geslacht in publieke en politieke sferen minder in te brengen thebben dan mensen van het mannelijke geslacht. Een grotere inbreng wan vrouwen zou ertoe kumnen leiden dat er meerdere perspectieven " waaronder genderperspectieven - in het publieke spreken over biotechnologie worden ingebracht, dan het ene biopolitieke perspectief.

Vrouwen zijnals product, als gebruker en als burger nauw betrokken bij biowetenschappelijke en technologische praktijken.

Ten eerste produceren biomedische wetenschappen nieuwe definities van wat vrouwen zijn, en wat sekse- en gender specifieke eigenschappen en ziektes zijn. Een voorbeeld is het onderzoek naar de seksespecifieke aanleg voor hoge ouderdiom. Ook in onderzoek nar oorzalken van borstkanker gaat de aandacht uit naar de seksespecifieke genetische aanleg: omgevingsfactoren worden irrelevant geacht (een stelling die door Amerikaanse en Britse borstkankeractivisten wordt aangevochten). Onder invloed van genetisch onderzoek verandert ook de betekeriis van sekse.

Ten tweede zijn vrouwen als gebrukers meer dan mannen aamwezig in praktijken wan genetica en biotechnologie. Vrouwen blijven woorlopig degenen die zwanger worden, abortussen ondergaan en kinderen baren. Het spreekt voor zich dat vrouwen op grond daarvan minstens een evenredige inbreng moeten hebben in de gesprekken over welke genetische testen al dan niet belangrijk zijn om te ontwikkelem en aan te bieden. Die evenredigheid kan ook worden onderbouwd wanuit de 
vaststelling dat vrouwen als proefpersonen deelnemen aan clinical trials, dat zij als consumenten met genetisch gemodificeerd voedsel in aanraking komen, en dat zij als toekomstige ouders, patiënten, moeders en consumenten te maken hebben met veranderende normen voor ziek en gezond, normaal en afwijkend, verantwoordelijk ouderschap, en een verantwoorde omgang met gebrek en gezondheid.

Ten derde hebben vrouwen als burgers van doen met publieke en politieke gesprekken, schrijfsels en verbeeldingen waarin ze vaker als onderwerp van gesprek dienen, dan dat ze zelf het gesprek voeren. Een meer evenwichtige inbreng is daarom op zijn plaats. Vooral omdat studies naar de inhoud en betekenis van het biotechnologisch spreken en handelen, en van het publieke en politieke spreken over onderwerpen als embryo-kweek of IVF aantonen dat deze gesprekken alles behalve genderneutraal zijn (Kirejczyk 1996, Sevenhuijsen 1998).

Vrouwen hebben tot op heden aanzienlijk minder in te brengen in publieke en politieke gesprekken over biotechnologie dan mannen. Ze zijn minder aanwezig in publieke en politieke puimtes, hun inbreng is minder effectief en wordt minder gehoord dan die van mannen. Het genderdemocratisch tekort is ook zichtbaar in de samenstelling van adviesraden, commissies, wetenschappelijke, economische en politieke instituties die richting geven aan de wetenschappelijke en technologische onderzoeksagenda's (Portegijs, Boelens en Keuzenkamp 2002, 175196). Hoewel democratie al zo'n 25 eeuwen bestaat, wordt aan de meest basale criteria van democratie - zoals gelijk stemrecht effectieve participatie in het ontwikkelen van beleid, het gelijkelijk en effectief de kans hebben om op de hoogte te raken van alternatieve beleidsvormen, en het gelijkellik en effectief op de agenda kunnen plaatsen van bepaalde zaken (Dahl ng98) - wat vrouwen betreft niet of nog maar sinds kort voldaan.

De remedie voor het gebrek aan vrouwen in publieke en politieke sferen wordt vaak verwacht wan het beroep op gelijke rechten. Met behulp van voorkeursbehandelingen zou het op den duur mogelijk moeten worden overal een gelijk aantal mannen en vrouwen aan het woord te laten. Gelijke rechten zijn echter maar één kant van de zaalk. Demoeratie bestaat bij de gratie van wat Chantal Mouffe "de democratische paradox" noemt: de spanning tussen enerzijds waardering voor liberale waarden, principes en rechten en anderzijds woor diversiteit en actief burgerschap (Mouffe 2000). Een gelijkelijke imbreng van vrouwen in publieke domeinen wordt deels bereikt door het beroep op gelijke rechten, maar wooral ook door burgerschap, dat wil zeggen door de moge- 
Ijkheden die vrouwen hebben om actief te bepalen hoe zij spreken en handelen, en het bestaan - in relatie tot anderen - vormgeven. Dat vergt geen heldhaftigheid, maar wel een behoorlijke dosis vrijmoedigheid.

\section{Wat is vrijmoedig spreken?}

Ik ontleen het begrip "vrijmoedig spreken" aan het latere werk van Foucault (1989). Hij trof de praktijk van vrijmoedig spreken aan in de antieke Griekse literatuur. In het Grieks is het "parrèsia", een samentrekking van "pan" (alles) en "rema" (dat wat gezegd wordt). lemand die parrèsia gebruikt is iemand die vrijuit, vrijmoedig en eerlijk spreekt. Hij spreekt vanuit zijn hart en ziel, vamuit een verstandig gemoed, zonder retoriek, zonder trucjes, en zonder tactisch of strategisch te willen zijn.

De inzet van het wrijmoedig spreken is waarheid. Niet de enige echte waarheid, maar datgene wat voor deze persoon binnen zijn huidige situatie als waarheid telt. Hij die wrijmoedig spreekt, la at zo openhartig magelijk blijken wat hij werkelijk gelooft. Het bewijs van zijn oprechtheid is de moed die vereist is om vrijmoedig te spreken. De parrèsiastès hoeft geen held te zijn, maar hij moet wel de vrijheid nemen om te zeggen wat hij denkt. In de Griekse literatuur is parresia altijd verbonden met gevaar: pas alls er aan het spreken van wartheid een gevaar of risico is verbonden is er sprake van parrèsia. Het gevaar komt van de ander, de gesprekspartmer aan wie de waarheid wordt getoond. Deze kan zich gekwetst woelen, een bepaalde waarheid niet willen horen, of zich in zijn positie bedreigd voelen. Het gevaar wordt bewerkstelligd door de ongelijkheid in positie: degene die vrijmoedig spreekt is altijd minder machtig dan degene met wie hij spreekt. Vrijmoedigheid komt als het ware "van onderen", en is gericht "naar boven". De leerling die zijn leraar bekritiseert, de burger die de meerderheid bekritiseert, of om een hedendaags voorbeeld te nemen, een patiënt die haar medisch specialist bekritiseert, zij allen kunnen als vrijmoedige sprekers worden getypeerd. In thet oude Griekenland kon echter niet iedereen vijimoedig spreken. Het was een voorrecht dat slechts toebedeeld was aan mannelijke vrije burgers. Alleen zij mocloten deelnemen aan het politieke leven. Je moest eerst burger zijn-dat wil zeggen vrij man - voordat je als parrèslastès waarheld kon spreken.

In de verplaatsing van het idee van vrijmoedigheid naar onze tijd, zou ik dit vertalen als dat vrouwen toe moeten treden tot publieke domeinen om in antwoord op Arendt's vraag "Wie ben jij?" duidelijk te maken wie zij zijn en wat zij vinden. In het uitspreken van de zin "Ik ben degene die dit of dat vindt" geeft de spreker zichzelf vorm door een warheid 
over zichzelf unt te spreken en maakt zij tegelijkertijd duidelik hoe de wormgeving van zichzelf samenhangt met haar overtuiging. Er is een overeenstemming tussen hoe zij haar bestaan wormgeeft en wat zij zegt.

Vrouwen zijn over het algemeen uitstekend in staat om te zeggen wat ze denken, en om openhartig en vrijmoedig hun meningen te ventilleren. Vaak heeft dit de vorn wan wat foucault een persoonlijke parrèsia noent. Het is een warheidhevende aanklacht tegen ienand die machtiger is dan zijzelf, en tegelijkertijd een bekentenis wan de waarheid omtrent zichzelf. Zoals Creusa in de lon van Euripides de God Apollo annklaagde omdat hij niet publiekelijk wilde toegeven dat hij haar had ver. kracht en een zoon bij haar had werwekt. Het is een vorm wan vrijmoedig spreken die tot een individuele bevrijding kan leiden, maar die niet of nauwelijks bijdraagt aan wat mensien, of vrowwen, gezamenlijk hebben.

De persoonlijk parresia wondt een politieke parresia op het moment dat het wrijmoedig spreken zich gaat afspelen tussen burgers als individuen, en ook tussen burgers die bijeen komen in groepen, netwerken, publieke ruimtes en politieke organisaties. Het politieke vrijmoedige spreken speelt zich af in een veelheid aan gedecentreerde publieke en politieke ruimtes 21 eeuwse agora's om met Nowotny scott en Gibbons te spreken): in kranten en tijdschriften, op straat, in televisiestudio's en achterafzalitjes, in politieke fora, in moskees, kerken en synagoges, in chatboxen, elektronische debatten en internetgroepen, en in de talloze ontmoetingen en onderhandelingen tussen degenen die vrijmoedig spreken en degenen tot wie het spreken is gericht. Het politieke vrijmoedig spreken is miet strategisch - in de zin dat vrouwen of feministen bedenken hoe zij kunnen bereiken dat een bepaalde technologie al dan niet ontwikkeld wordt. Het is een instrument of techniek (techne) om het eigen bestaan in te brengen in bestaande manieren van spreken - en in onderhandelingen met wetenschappers, politici, journalisten en wele anderen. De techniek van het vrijmoedig spreken wordt gebruikt om meerdere en andere perspectiveven, kenniswormen en verhalen een plats te geven in de sociale en polltieke orde. Het is een handelen dat de wereld (mede) vormgeeft.

Het aktief uitspreken van warkeden en owertuigingen in publieke domeinen kan processen in gang zetten waarin waarheden en verhalen worden uitgewisseld, conflicterende visies worden uitgediept en meningen worden gevormd of bijgesteld. Nieuwe technieken, warheden, objecten, mediaties, normen en waarden worden in deze processen geijkt aan wat men ith het bestaan waar, goed, juist, correct, interessant 
of mooi windt. Nelly Oudshoorn omschrifft de rol van de hedendaagse feministische kritiek als dat 'wij onszelf als actieve deelnemers in de constructie van betekenissen moeten positioneren'. Er moeten nieuwe verhalen toegevoegd aan het bestaande repertoire (Oudshoorn 2001, 209). Gerelateerd aan biomedische wetenschappen betekent dit dat vrouwen hun context - hun waarheden, envaringen, betekenissen, verhalen en overtuigingen - inbrengen in publieke en wetenschappelijke gesprekken over biotechnologie, en op die manier het discursieve biomedische veld beinvloeden - en voor cen deel naar hun hand zetten. Een voorbeeld hiervan is de recente verandering in de wetenschappelijke representatie van de bevruchting. De eicel wacht niet langer passief de penetratie van de actieve spermacel af, maar blijkt een actieve partner in het vinden van en samenvloeien met de zaadcel. Deze verandering is toe te schrijven aan de impact die veranderende culturele concepties van gender hebben op de biomedische wetenschappen (Keller 2001, 106). Het inbrengen van de context leidt er ook toe dat vrouwen in interactie met anderen hun mening vormen over hoe technologieën en vormen van kennis al dan niet ingelijfd kunnen worden in hun bestaan.

In sommige gevallen zal de communicatie in publieke ruimtes leiden tot een eenstemmig handelen - zoals vrouwenorganisaties wereldwijd collectief protest aantekenden tegen de patentaanvraag wan het Amerikaanse biotechnologiebedrijf Myriad Genetics op de ontdekking wan het borstkankergen BRCA1 (Rifkin 1998, 63). Vaker zal het echter gebeuren dat vrouwen niet met eén stem spreken. Een eensluidende mening over genetische testen, klonen of het kweken van embryo's voor medisch-wetenschappelijk onderzoek is niet te verwachten. Juist omdat vrouwen niet hetzelfde zijn en niet dezelfde overtuigingen hebben, is het belangrijk om verschillen in mening onbekommerd uit te spreken. In plaats van te streven naar consensus (de vrouwenbeweging denkt zus of zo over klonen'), moeten vrouwen hun verschillen in meningen, voorkeuren, smaken en overtuigingen actief imbrengen in publieke ruimtes. Intellectuelen kunnen daaraan bijdragen door werschillen scherper neer te zetten - een taak die past bij de kritische functie die het vrijmoedig spreken heeft ten aamzien van heersende politieke en culturele denk- en spreekwijzen. Met hun kennis van biomedische wetenschappen en hun wardigheden in schrijven, spreken en analyseren kunnen zij zaken complexer maken, en spanningsvelden uitbaten zoals René Gabriëls (2001) het noemt - een activiteit die in een consensussamenleving als Nederland haast tegennatuurlijk lijkt. Het compliceren van zaken is vergelijkbaar met het aanleggen van een ingewikkeld en wijdvertakt laby- 
rint. Hoe meer ruimtes er zijn om eigen inzichten op zeer diverse manieren in te brengen, en vrijmoedig en openhartig uit te drukken "wie je bent en wat je vindt", hoe groter de mogelijkheden om actief te participeren in hoe de wereld eruit ziet.

Betekent het dat we met het politieke vrijmoedig spreken werzekerd zijn van een gelijkelijke inbreng van vrouwen op het gebied wan biotechnologie? Gezien de historisch gegroeide democrat ische achterstand van wrouwen is dat onwaarschijnlijk. Toch is het niet aan overheden om mensen aan te zetten tot actief burgerschap. Overheden hebben wel een taak in het beschermen van initiatieven die burgers nemen. Overheden kumnen erop toezien dat stemmen van vrouwen niet gemar"ginaliseerd of buitengesloten worden. De positie van vrouwen die vijmoedig in publieke sferen spreken moet velilig gesteld worden, wooral waar massamedia de politieke sfeer domineren. Overheden zijn er ook om interacties tussen wetenschappers en burgers te stimuleren. bijvoorbeeld door nieuwe experimenten in democratie aan te gaan, door feministische wetenschapsfilosofen, wetenschapsjournalister of andere intellectuelen uit te nodigen kritische beschouwingen te maken over nieuwe richtingen in de biomedische wetenschappen - waarin ruimte is voor kritische deconstructies van de processen die wetenschap, technologieën, lichamen en ziektes vormgeven en voor het onderzoeken van alternatieve wegen die wetenschap en technolgie kunnen inslaan (Oudshoorn 2001). Overheden kunnen bijdragen door vrouwen de toegang tot wetenschappelijke publicaties te garanderen, en door regelmatig onderhandelingen en gesprekken tussen wetenschappers en vrouwenorganisaties te stimuleren. Het naar de agora's roepen van wetenschappers is echter niet voorbehouden aan overheden; burgers, vrouwen, vrouwenorganisaties en vele anderen kunnen dat eveneens doen. En, zoals vandaag is gebleken, een toenemend aantal biomedische wetenschappers is bereid met deze diversiteit aan publieken in gesprek te gaan. Laten we daar vooral vrijpostig mee omgaan. 


\section{Dankwoord}

Datnes en heren,

Aan het einde van deze oratie will ik een woord van dank witspreken aan alle mensen die deze leerstoel en mijn bekleding ervan mogelijk hebben gemaakt. Allereerst wil ik Stichting Opzij en de Universiteit Maastricht danken voor het im mij geschonken vertrouwen. Ik vind het een eer na Maaike Meijer en Liesbet van Zoonen deze leerstoel als derde te mogen bekleden. Mijn collega's op het Centrum voor Gender en Diversiteit dank ik woor de hartelijke manier waarop ze mij in het centrum hebben opgenomen. In het bijzonder wil ik Maaike Meijer, Mineke Bosch, Wilma Lieben, Judith Malas, Irene Duyn, Ineke Klinge. Agnes Andeweg en Annelies van der Horst noemen, die mij deze eerste maanden met raad en daad hebben bijgestaan bij het organiseren wan het genderdemocratisch labyrint dat vanmiddag heeft plaatsgevonden. Mijn collega's uit de Medische Faculteit, Faculteit Zorgwetenschappen, en Faculteit der Cultuurwetenschappen wil ik danken voor hun bijdragen aan dit experiment in democratie. Ook alle andere deelnemers wil ik danken voor thun bereld heid publiekelijk hun meningen en verhalen te vertellen - en zo bij te dragen aan publieke gesprekken over het kweken van embryo's voor medisch-wetenschappelijk onderzoek. In het bijzonder wil ik Krien Clevis danken, die het organiseren van interacties tussen wetenschappers en kunstenaars tot een eigen kunstvorm heeft gemaakt. De waardering die we van NWO, de Universiteit Maastricht en de gemeente Maastricht in materiële zin voor het labyrint ontvingen, stelde ons in staat om het experiment werkelijk uit te voeren. Loet Hin en Irene Janze wil ik speciaal bedanken - het is een groot genot om met jullie samen te werken.

Gender, democratie en biomedische wetenschappen zal ook de komende tijd het hoofdthema van mijn onderzoek zijn. Rond dat thema organiseer ik in mei een serie lezingen. Ook zal ik samen met Klasien Horstman, met wie ik een grote bellangstelling voor genetica deel, over dit thema een boek schrijwen dat voorjaar 2004 zal verschijnen. Over het genderdemocratisch labyrint kunt $u$ eveneens publicaties tegemoet zien.

Itk ben erg verheugd dat ik aan de Universiteit Maastricht collega"s terugvind die ik wit een vroeger leven ken: Rob Houtepen, Rein Vos en Guy Widdershoven als bestuursleden van de Vereniging voor Filosofie en Geneeskunde, André Knottnerus die mij als eerste in contact bracht met de filosofie van de geneeskunde. Ook de contacten met Bernike Pasveer en Jessica Mesman stoelen op eerdere ontmoetingen. 
Ik will daarnaast mijn collega's Praktische Filosofie, van de Faculteit Wijsbegeerte in Groningen danken. Zelfs nu ik minder in het noorden ben, blijft het contact intensief. I wil met name Baukje Prins, Katherine Gardiner, René Boomkens, Martin van Hees en Hans Harbers noemen. Jullie zijn voor mij het levende bewijs dat gezamenlijkheid meer gediend is bij verschil van mening dan bij consensus. Hans Harbers wil ik speciaal danken. Niet alleen omdat hij - net alls Jessica Mesman - deze oratietekst kritisch onder de loep heeft genomen, maar ook omdat hij mijn beste sparring partner is in het gesprek over wetenschap en technologie. Over de relatie tussen politiek en wetenschap zullen we het wel nooit eens worden. De tijd zal het leren.

Ook dank ik de vele vrienden en collega's die mij op mijn tocht door de universitaire wereld hebben bijgestaan en geinspireerd. Als eerste Hans Achterhuis bij wie ik afstudeerde en promoveerde. Ook Kathy Davis is een constante factor in de verschillende fasen van mijn leven. van de periode dat ik in Nijmegen werkte wil ik Machiel Karskens noemen, met wie ik een grote passie voor Foucault deel, Veronica Vasterling en Daan Roovers. Van mijn werk in Amsterdam: Heleen van Luijn, Dick Willems, en Bert Musschenga. Ook letje van Dongen, Henriëtte van der Horst en alle andere vrouwen van de oude Vrouwengezondlheidsgroep aan de Vu wil ik danken voor de vele inspirerende bijeenkomsten

Op een dag als vandaag zou ik even weer ouders willen hebben, maar dat zit er niet in. Ik dank mijn broer Ruud dat hij hier wel aanwezig is. En verder dank ik mijn vrienden, vriendinnen en buren die mij erg doen genieten van het leven buiten de universiteit. Liesbeth Randag en Irene Janze will ik danken voor hun vele vormen van vriendschap - met jullie is het niet alleen goed schaatsen maar ook lekker ouwehoeren. Jeam, iech weit 't. Gezeen de kontex hat iech dee'z oratie in ut Mestreechs moote häwwe. De versjelle tusse "nne Amsterdammer en "nne Mestreechteneer zien groet. Sjus daorum, bis te al einentwintig jaor deginnige dee al in de vreugste stadiums met miech met dink, miech stimuleert en op ut ajuste momint commentalar gief. En vooral danik ik Nico en Daan-zonder jullie zou ik hier vandaag niet staan. Deze oratie draag ik aan jullie op.

Ik dank u hartelijk voor uw aandacht. 


\section{Literatuiur:}

- Arendt, H. The Human Condition. Chicago: University of Chicago Press, 1998 (eerste uitgave 1958 ).

- Borges, J. Li De Aleph en andere verhalen. Amsterdam: De Bezige Bij, 1993.

- Dahl, R. A. On democracy. New Haven: Yale University Press, 1998.

- Flower, M. I., Heath, D. Micro-Anatomo Politics Mapping the Humam. Genome Project. Culture, Medicine and Psychiatry 1993. 17: 27-41.

- Foucault, M. Surveiller et Punir. Naissance de la Prison. Paris: Gallimard, 1975.

- Foucault M. Parrèsia. Vrijmoedig spreken en waarheid. Amsterdam: Stichting woor Filosofisch Onderzoek/Krisis, 1989.

- Fredrickson, D.S. Asilomar and Recombinant DNA: The end of the beginning. \|n: K.E. Hanna (ed.), Biomedical Politics. Washington, DC: National Academy Press, 1991: 258-307.

- Gabriëls, R. Intellectuelen in Nederland. Publieke controverses over kernenergie, armoede en Rushdie. Amsterdam: Boom, 2001.

- Keller, E. F., The Century of the Gene. Cambridge, MA: Harvard University Press, 2000.

- Keller, E.F.Making a Difference: Feminist Movement and feminist critiques of science. In: A.N.H. Cregare, E. Linbeck \& L. Schiebinger. Feminism in twentieth-century science. technology and medicine. Chicago, University of Chicago Press, 2001: 98-109.

- Kirejczyk. M. Met technologie gezegend? Gender en de omstreden invoering wan in vitro fertilisatie in de Nederlandse gezondheidszorg. Utrecht: Jan van Arkel, 1996.

- Mouffe, C. 2000. The Democratic Paradox. Londen: Verso

- Nelkin, D., Andrews, L., DNA Identification and Surveillance Creep. In: P. Conrad en J. Gabe, (eds.), Sociological Perspectives on the New Genetics. Blackwell Publishers, Oxford UK, 1999:191-208.

- Nowotny. H. P. Scott and M. Gibbons. Re-Thinking Sciente. Knowledge and the public in an age of uncertainty. Cambridge UK, Polity Press, 2001.

- NWO/Medische Wetenschappen, werkgroep genomics/biomedisch. van genoom naar gerondheid. Functional genomics vanuit een medisch perspectief. Den Haag, mei 2000.

- Oudshoom, N. On Bodies, technology, and feminisms. In: A.N.H. Cregare, E. Linbeck \& L. Schiebinger, 2001: 199-213.

- Portegijs, W. Boelens, A. Keuzenkamp. 5. Emancipatiemonitor 2002. Den Haag, Sociaal en Cultureel Planbureau, 2002. 
- Rifkin. J. The Biotech Cemtury. Harnessing the Cene and Remaking the World. New York: Tarcher/Putnam, 1998.

- Rose, N. The Politics of Life Itself. Theory, Culture \& Society 2001: 18(6): $1-30$.

- Sevenhuijsen, 5. De vrijgevochten foetus. Gender en individualisme in het bio-ethisch debat over de persoonsstatus van het menselijk embryo. Tijdschrift voor Genderstudies 1998; 1: 16-24.

- Tijdelijke Adviescommissie Kennisinfrastructuur Genomics. Advies. Den Haag, april 2001. 